\title{
Performance and Blood Profile of Grower West African Dwarf (WAD) Bucks Fed Graded Levels of Toasted Baobab (Adansonia digitata) Seed Meal
}

\author{
Rose Nenrotmwa Yakubu1, John Adisa Ayoade², Juliana Oloche², Stephen Azi Ashom1 \\ ${ }^{1}$ Department of Animal Production Technology, Plateau State College of Agriculture, Garkawa, Nigeria \\ ${ }^{2}$ Department of Animal Production, University of Agriculture Makurdi, Makurdi, Nigeria \\ Email: roseyakubu2013@gmail.com
}

How to cite this paper: Yakubu, R.N., Ayoade, J.A., Oloche, J. and Ashom, S.A. (2022) Performance and Blood Profile of Grower West African Dwarf (WAD) Bucks Fed Graded Levels of Toasted Baobab (Adansonia digitata) Seed Meal. Open Journal of Animal Sciences, 12, 58-67.

https://doi.org/10.4236/ojas.2022.121004

Received: September 27, 2021

Accepted: December 6, 2021

Published: December 9, 2021

Copyright $\odot 2022$ by author(s) and Scientific Research Publishing Inc. This work is licensed under the Creative Commons Attribution International License (CC BY 4.0).

http://creativecommons.org/licenses/by/4.0/

\begin{abstract}
An experiment was conducted to evaluate the performance and blood parameters of West African Dwarf (WAD) bucks fed graded levels of toasted baobab seed meal for 84 days. Baobab seeds were washed, sun-dried and toasted uniformly using a cast iron pan. The toasted baobab seeds were crushed with a roller mill grinding machine to make baobab seed meal (BSM). The BSM was included at $0 \%, 25 \%, 50 \%$ and $75 \%$ levels in diets $1,2,3$ and 4 respectively to replace soybean. Each treatment was replicated four times in a completely randomized design. Uncoagulated blood samples were collected from WAD bucks at the end of the 84 days' feeding trial and analysed for packed cell volume (PCV), haemoglobin concentrate (Hb), red blood cells (RBC) and white blood cells (WBC). The mean corpuscular haemoglobin volume (MCV), mean corpuscular haemoglobin $(\mathrm{MCH})$, platelets, neutrophils, lymphocytes, monocytes, eosinophils, and basophils were calculated using PCV, RBC and $\mathrm{Hb}$. The blood meant for serological analysis was centrifuged at $1000 \mathrm{G}$ for 10 minutes, after which the serum was separated and used for determining serum total protein $(\mathrm{Tp})$, albumin, serum glutamic oxaloacetic transaminase (SGOT) and serum glutamic pyruvic transaminase (SGPT). The inclusion of baobab seed meal up to $50 \%$ in the experimental diet did not have any negative effect on the performance of the goats and did not pose any health challenge to the animals during the study period.
\end{abstract}

\section{Keywords}

Baobab, Performance, Blood, Haematology, Biochemistry 


\section{Introduction}

The high cost of conventional protein sources has made their incorporation in small ruminant diets uneconomical, hence the increased focus for their replacement by researchers. Use of less popular protein sources such as baobab seed has been reported to give less cost/kg weight gain [1].

Adansonia digitata (baobab tree) is a drought and fire-resistant tree that is found in most parts of Africa, including the deserts [2]. It is an indigenous leguminous plant that is cheap, readily available in the northern parts of Nigeria and its products are utilized for nutritional and medicinal purposes [3]. Adansonia digitata seed contains anti-nutritional factors such as oxalates (10\%), phytates $(2 \%)$, saponins $(3 \%-7 \%)$ and tannins $(9 \%-12 \%)$ which if not properly processed might limit its utilization in livestock feeding. These levels of the anti-nutritional factors are below the toxic level for most livestock species if properly treated [3]. While these anti-nutritional factors may not pose a challenge to ruminants because of the presence and activities of microbes in the rumen, better utilization may be achieved if the seeds are processed [1] [4].

It has been suggested that the use of different methods to process less popular feed-stuff will help to achieve their optimum benefits for ruminants [5]. Haematological indices of animals may give some insight into the performance potentials of West African Dwarf goats [6]. Nutrition, breed, sex, age, reproductive status, environmental factors, stress and transportation are known to affect haematological parameters of animals [7].

This research seeks to evaluate the effect of processing on the utilization of baobab seed meal, performance and blood profile of WAD goats.

\section{Materials and Methods}

\subsection{Location and Climatic Conditions of the Study Area}

The study was conducted on a private farm in North Bank within Makurdi metropolis of Benue State. Makurdi is located between latitude $7^{\circ} 68^{\prime} \mathrm{N}$ and longitude $8^{\circ} 62^{\prime} \mathrm{E}$. The flood plain is between $106 \mathrm{~m}$ to $113 \mathrm{~m}$ above sea level, the area is warm with a minimum temperature range of $17.3^{\circ} \mathrm{C}$ to $24.5^{\circ} \mathrm{C}$ and a maximum temperature range of $29.8^{\circ} \mathrm{C}$ to $35.6^{\circ} \mathrm{C}$. During the dry hot season between February and March, temperature may reach $40^{\circ} \mathrm{C}$, and rainfall is between 1500 $\mathrm{mm}$ to $1800 \mathrm{~mm}[8]$.

\subsection{Collection and Preparation of Baobab Seeds}

Adansonia digitata (baobab) seed pods were collected directly from farmers located in Amper, Kanke L.G.A in Plateau State. The baobab seed pods were crushed to remove the seeds and pulp together. The seed and pulp were soaked in water for one hour to soften the pulp and easy remove the pulp, after which the seeds were thoroughly washed and sun-dried. The dried baobab seeds were divided into two with the first part left raw. The second part was toasted using a 
cast iron pan set over an open fire and stirred continuously to ensure uniform toasting and to prevent charring. When it turned dark brown, it was taken out of the pan to cool. The two different samples of the baobab seeds were then crushed separately using a burr mill to give the Baobab Seed Meal (BSM). Other ingredients used included burkutu spent grain, maize offal, full-fat soya bean meal, bone ash and common salt.

Fresh gmelina (Gmelina arborea) leaves and stalk were harvested within the experimental site and used as the basal diet.

\subsection{Experimental Animals and Management}

A total of sixteen grower West African dwarf bucks of 5 - 7 months of age were purchased from Makurdi metropolis and environs. The bucks were quarantined on arrival and vaccinated against pestes des petite ruminants (PPR). Ivermectin was administered to control both endo and ecto-parasites, before the feeding trial began.

The experimental house was a high walled building with wide windows and high roof for cross ventilation. The house was divided into pens and each pen was divided into individual compartments. The floor made of concrete was covered with wood shavings to serve as litter material and beddings. Feed troughs and drinkers were kept in each compartment which were cleaned daily and the litter materials changed forth-nightly or as the need arose to ensure good sanitation. A week to the arrival of the animals, the house was thoroughly washed with detergent and disinfectant (izal) and allowed to dry before introducing wood shavings to each compartment. The drinking troughs and feeders were also thoroughly washed and sun-dried before placing them in the individual compartments. On arrival, the animals were allowed a period of fourteen days to acclimatize to the feed and environment before data collection commenced. Thereafter, all the animals were weighed and randomly distributed into four treatments of four replicates each. The animals were subsequently weighed to determine their weight gain in each week. At the commencement of the study, weighed quantities of feeds were supplied to each animal, and the left over feeds were weighed at the end of each week and deducted from the feed supplied at the beginning of the week to determine feed intake. They were fed with concentrates at 08:00 hour and later fed with gmelina at 10:00 hour and 15:00 hour daily. The feeding was done at different times to reduce feed wastage and encourage intake by the animals. Mineral supplements were provided for each animal in form of mineral blocks. Fresh clean water was provided to the experimental animals ad libitum daily.

\subsection{Experimental Diets}

Four experimental diets were formulated to contain $0 \%, 25 \%, 50 \%$ and $75 \%$ toasted baobab seed meal and designated as T1, T2, T3 and T4 respectively (Table 1). Diet 1 (T1) was the control. 
Table 1. Gross composition of experimental diets.

\begin{tabular}{|c|c|c|c|c|}
\hline \multicolumn{5}{|c|}{ Experimental Diet } \\
\hline Ingredients & $\mathrm{T} 1$ & $\mathrm{~T} 2$ & T3 & $\mathrm{T} 4$ \\
\hline M.O & 71.49 & 71.49 & 71.49 & 71.49 \\
\hline FFSBM & 20.51 & 15.38 & 10.25 & 5.13 \\
\hline BSM & 0.00 & 5.13 & 10.25 & 15.38 \\
\hline BSG & 5.00 & 5.00 & 5.00 & 5.00 \\
\hline Bone ash & 2.00 & 2.00 & 2.00 & 2.00 \\
\hline Common Salt & 1.00 & 1.00 & 1.00 & 1.00 \\
\hline & 100.00 & 100.00 & 100.00 & 100.00 \\
\hline \multicolumn{5}{|c|}{ Calculated Analysis (\%) } \\
\hline Crude Protein & 17.00 & 16.50 & 15.99 & 15.49 \\
\hline Crude Fibre & 9.97 & 10.48 & 10.99 & 11.50 \\
\hline Ether Extract & 5.95 & 6.59 & 7.23 & 7.88 \\
\hline Nitrogen-free Extract & 67.08 & 66.43 & 65.79 & 65.13 \\
\hline Ash & 3.88 & 3.98 & 4.08 & 4.18 \\
\hline ME (kcal/kg) & 3463.51 & 3474.61 & 3485.69 & 3497.26 \\
\hline
\end{tabular}

BSG: Burkutu spent grain; M.O: Maize offal; BSM: Baobab seed meal; FFSBM: Full fat soyabean meal; M.E: Metabolizable energy. Metabolizable energy was calculated according to the formula of Pauzenga (1989).

\subsection{Performance Parameters and Blood Sample Collection}

Blood samples were collected from the jugular vein of the WAD goats on the 84th day of the feeding trial in the morning before feeding using needles and syringes. Five millilitres $(5 \mathrm{ml})$ of blood was collected from the jugular veins of the goats in each replication using syringes and needles, and preserved in plastic sample bottles containing ethylene diamine tetraacetic acid (EDTA) for haematological analysis. The parameters analysed werepacked cell volume (PCV), haemoglobin concentration ( $\mathrm{Hb})$, red blood cells (RBC), white blood cells (WBC) and the mean corpuscular volume (MCV). The mean corpuscular haemoglobin $(\mathrm{MCH})$, mean corpuscular haemoglobin concentration $(\mathrm{MCHC})$, platelets, neutrophils, lymphocytes, monocytes eosinophils and basophils were determined by calculation.

\subsection{Sample Analysis}

The chemical analysis of feed samples and blood samples were determined [9] method while all data collected were subjected to analysis of variance (ANOVA) as described by [10]. Treatment means were separated and compared using the Duncan Multiple range test using statistical software [11]. 


\section{Results}

Performance parameters of West African Dwarf goats fed diets containing graded levels of toasted baobab seed meal (BSM) are shown in Table 2. There was no significant $(\mathrm{P}>0.05)$ difference in final body weight but total weight gain and mean daily weight gain were significantly $(\mathrm{P}<0.05)$ different. The total weight gain ranged from $2.51 \mathrm{~kg}$ (T4) to $3.84 \mathrm{~kg}$ (T1) with the highest value recorded in $\mathrm{T} 1(0 \% \mathrm{BSM})$ which was closely followed by $\mathrm{T} 2(3.48 \mathrm{~kg})$ containing $25 \%$ of toasted Baobab Seed meal. Feed intake values were not significantly ( $\mathrm{P}>$ $0.05)$ different among treatments, but mean daily feed intake was significantly $(\mathrm{P}$ $<0.05$ ) different and ranged from $0.35 \mathrm{~kg}$ to $0.37 \mathrm{~kg}$. The feed conversion ratio recorded were $33.13,34.08,35.60$ and 42.52 for $\mathrm{T} 1, \mathrm{~T} 2$, T3 and T4 respectively.

Haematological parameters of WAD bucks fed the experimental diets are presented in Table 3. Dietary treatment had no significant $(P>0.05)$ effect on Packed cell volume (PCV), Haemoglobin (Hb), Mean corpuscular haemoglobin (MCH) and Mean corpuscular haemoglobin concentration (MCHC). PCV values were $31.75 \%, 29.25 \%, 29.25 \%$ and $28.00 \%$ in $\mathrm{T} 3, \mathrm{~T} 1$, $\mathrm{T} 4$ and $\mathrm{T} 2$ respectively. $\mathrm{Hb}$ concentration were $10.58,9.50,9.50$ and $9.33 \mathrm{~g} / \mathrm{dl}$ in the same order. Mean corpuscular haemoglobin gave 7.88, 8.05, 9.20 and 11.00 pictogram for T4, T3, $\mathrm{T} 1$ and $\mathrm{T} 2$ respectively while the $\mathrm{MCHC}$ values recorded were $33.33,33.28,33.30$ and 32.40 for $\mathrm{T} 1, \mathrm{~T} 2, \mathrm{~T} 3$ and $\mathrm{T} 4$ respectively. Red blood cells (RBC), White blood cells (WBC) and Mean corpuscular volume were significantly $(\mathrm{P}<0.05)$ different. RBC contents were $9.40,12.60,13.00$ and $13.80 \times 10^{12 / 1}$ for T2, T4, T1

Table 2. Performance of WAD goats fed experimental diets.

\begin{tabular}{|c|c|c|c|c|c|}
\hline \multirow{2}{*}{ Parameters } & \multicolumn{5}{|c|}{ Experimental Diets } \\
\hline & $\mathrm{T} 1$ & $\mathrm{~T} 2$ & $\mathrm{~T} 3$ & $\mathrm{~T} 4$ & SEM \\
\hline Initial body weight (kg) & 6.23 & 6.30 & 6.30 & 6.30 & - \\
\hline Final body weight (kg) & $10.10^{\mathrm{a}}$ & $9.78^{\mathrm{a}}$ & $9.33^{\mathrm{ab}}$ & $8.81^{\mathrm{b}}$ & $0.69^{*}$ \\
\hline Total weight gain $(\mathrm{kg})$ & $3.84^{\mathrm{a}}$ & $3.48^{\mathrm{a}}$ & $3.03^{\mathrm{ab}}$ & $2.51^{\mathrm{b}}$ & $0.48^{*}$ \\
\hline Mean daily weight gain (kg) & $0.046^{\mathrm{a}}$ & $0.037^{\mathrm{ab}}$ & $0.036^{\mathrm{ab}}$ & $0.029^{b}$ & $5.17^{\star}$ \\
\hline Total concentrate intake $(\mathrm{kg})$ & 8.78 & 8.57 & 8.42 & 8.56 & $0.30 \mathrm{~ns}$ \\
\hline Total forage intake (kg) & $22.72^{\mathrm{a}}$ & $22.02^{\mathrm{a}}$ & $21.08^{\mathrm{ab}}$ & $21.15^{\mathrm{ab}}$ & $0.54^{\star}$ \\
\hline Mean daily feed intake $(\mathrm{kg})$ & 0.375 & 0.364 & 0.354 & 0.353 & $8.43 \mathrm{~ns}$ \\
\hline Total feed intake (kg) & 31.50 & 30.59 & 29.71 & 29.50 & $0.72 \mathrm{~ns}$ \\
\hline Feed conversion ratio & 33.13 & 34.08 & 35.60 & 42.52 & $5.72 \mathrm{~ns}$ \\
\hline
\end{tabular}

a, b: Means within the same row bearing different superscripts differ significantly $(\mathrm{P}<$ 0.05). *: Significant; ns: Not significant; SEM: Standard error of mean. 
Table 3. Haematological parameters of WAD goats fed experimental diets.

\begin{tabular}{cccccc}
\hline \multicolumn{5}{c}{ Experimental Diets } \\
\hline Parameter & T1 & T2 & T3 & T4 & SEM \\
\hline PCV (\%) & $29.25^{\mathrm{ab}}$ & $28.00^{\mathrm{b}}$ & $31.75^{\mathrm{a}}$ & $29.25^{\mathrm{ab}}$ & $1.53 \mathrm{~ns}$ \\
HB (g/dl) & $9.50^{\mathrm{ab}}$ & $9.33^{\mathrm{ab}}$ & $10.58^{\mathrm{a}}$ & $9.50^{\mathrm{ab}}$ & $0.54 \mathrm{~ns}$ \\
RBC $\left(10^{12 / 1}\right)$ & $13.00^{\mathrm{a}}$ & $9.40^{\mathrm{b}}$ & $13.80^{\mathrm{a}}$ & $12.69^{\mathrm{ab}}$ & $1.78^{\star}$ \\
WBC (10 & $12.1)$ & $15.50^{\mathrm{a}}$ & $14.60^{\mathrm{a}}$ & $7.25^{\mathrm{b}}$ & $2.48^{\star}$ \\
MCV (fl) & $24.55^{\mathrm{ab}}$ & $33.00^{\mathrm{a}}$ & $24.00^{\mathrm{ab}}$ & $23.98^{\mathrm{ab}}$ & $4.33^{\star}$ \\
MCH (pg) & 9.20 & 11.00 & 8.05 & 7.88 & $1.48 \mathrm{~ns}$ \\
MCHC (g/dl) & 33.33 & 33.28 & 33.30 & 32.40 & $0.47 \mathrm{~ns}$ \\
\hline
\end{tabular}

a, b: Means within the same row bearing different superscripts differ significantly $(\mathrm{P}<$ 0.05). SEM: Standard Error of Mean; ${ }^{*}$ : Significant; ns: Not significant; PCV: Packed Cell Volume; Hb: Haemoglobin Concentration; RBC: Red Blood Cell; WBC: White Blood Cell; MCV: Mean Corpuscular Volume; MCH: Mean Corpuscular Haemoglobin; MCHC: Mean Corpuscular Haemoglobin Concentration.

and $\mathrm{T} 3$ respectively. $\mathrm{WBC}$ values were $15.50,14.60,12.80$ and $7.25 \times 10^{9 / 1}$ for $\mathrm{T} 2$, T3, T1 and T4. Mean corpuscular volume produced 33.00, 24.55, 24.00 and 23.98 femtolitre for T2, T1, T3 and T4 respectively. Total protein, albumin, globulin, cholesterol, creatinine, urea and alkaline phosphate of WAD bucks fed the experimental diets were presented in Table 4 where there were no significant $(\mathrm{P}>$ $0.05)$ differences among the dietary treatments except for serum transaminases (ALT and AST).

\section{Discussion}

Performance of the WAD bucks as presented in Table 2 showed no significant $(\mathrm{P}>0.05)$ difference in final body weight. Total weight gain varied significantly $(\mathrm{P}<0.05)$ among dietary treatments with bucks in the control recording the highest weight gain $(3.84 \mathrm{~kg})$. However, it was observed that bucks in T2 (3.48 $\mathrm{kg}$ ) had similar weights and comparable with the control. The average weight gain obtained in this study was higher than the weight gain $(2.09 \mathrm{~kg}-3.26 \mathrm{~kg})$ reported by [1] for fermented Baobab seed meal used to replace Palm kernel cake and the range $(2.35 \mathrm{~kg}-2.52 \mathrm{~kg})$ reported by [12] for Baobab whole fruit and Pulp meal as supplement to wheat offal. A corresponding significant $(\mathrm{P}<$ $0.05)$ mean daily weight gain was recorded for $\mathrm{T} 1(0.046 \mathrm{~kg})$ followed closely by goats on $25 \%$ BSM, $(0.037 \mathrm{~kg}), 50 \%$ BSM, $(0.036 \mathrm{~kg})$ while the lowest was by goats on $75 \%$ BSM, T4 $(0.029 \mathrm{~kg})$. This means that nutrient contribution of diet containing BSM was adequate for growth. There was no significant $(P>0.05)$ difference in feed intake. Feed intake was reported to be governed by dietary Crude Protein, palatability and other factors like gut fill in WAD goats fed cassava peel based diets [13]. Feed conversion ratio was not significant as reported by [1] for fermented Baobab seed meal fed to WAD goats. 
Table 4. Serum biochemical indices of WAD goats fed treatment diets.

\begin{tabular}{cccccc}
\hline \multicolumn{5}{c}{ Treatment Diets } \\
\hline Parameters & T1 & T2 & T3 & T4 & SEM \\
\hline T-Protein & 4.93 & 5.45 & 5.43 & 4.73 & $0.99 \mathrm{~ns}$ \\
Albumin & 3.00 & 3.05 & 3.30 & 3.03 & $0.22 \mathrm{~ns}$ \\
Globulin & 1.78 & 2.40 & 2.13 & 1.70 & $1.06 \mathrm{~ns}$ \\
Cholesterol & 103.38 & 93.05 & 99.92 & 107.35 & $18.57 \mathrm{~ns}$ \\
Urea & 24.80 & 28.05 & 34.65 & 35.65 & $9.81 \mathrm{~ns}$ \\
Creatinine & 2.18 & 2.00 & 2.10 & 1.98 & $0.76 \mathrm{~ns}$ \\
AST (u/l) & $20.95^{\mathrm{ab}}$ & $14.75^{\mathrm{b}}$ & $16.27^{\mathrm{b}}$ & $35.50^{\mathrm{a}}$ & $5.05^{\circ}$ \\
ALT (u/l) & $51.47^{\mathrm{a}}$ & $14.85^{\mathrm{bc}}$ & $33.58^{\mathrm{b}}$ & $46.83^{\mathrm{ab}}$ & $11.50^{\circ}$ \\
ALP $(\mathrm{u} / \mathrm{l})$ & 43.88 & 46.42 & 46.83 & 41.40 & $9.66 \mathrm{~ns}$ \\
\hline
\end{tabular}

SEM: Standard Error of Mean; ns: Not significant.

The blood profile of WAD goats fed the experimental diets are presented in Table 3 and Table 4. The PCV, $\mathrm{Hb}$ and $\mathrm{MCH}$ were not significantly $(\mathrm{P}>0.05)$ different. The PCV values $(28.00 \%-31.75 \%)$ in this study were within the normal range $(21 \%-35 \%)$ reported by [14] for healthy goats. Haemoglobin $(\mathrm{Hb})$ is estimated to assess the oxygen carrying capacity of the blood circulatory system. The $\mathrm{Hb}$ concentration in this study ranged from $9.33 \mathrm{~g} / \mathrm{dl}$ (T2) to $10.58 \mathrm{~g} / \mathrm{dl}$ (T3) among treatment groups. This is within the normal range of $8-15 \mathrm{~g} / \mathrm{dl}$ reported for normal blood functions by [14] and [15]. The Hb values showed that the experimental diets were adequate for the nutritional requirement and BSM did not pose any danger to the goats. Red blood cells $(\mathrm{RBC})$ carry respiratory pigments which include $\mathrm{Hb}$, a decrease in the quantity of the circulating RBC shows there is a decrease in the quantity of $\mathrm{Hb}$ and this reduces oxygen carrying capacity of the animal. RBC count ranged from $9.40 \times 10^{6} / \mathrm{ml}$ to $13.80 \times 10^{6} / \mathrm{ml}$ and there was significant difference $(\mathrm{P}<0.05)$ among treatment groups. The values of RBC were comparable to the range of $9.20 \times 10^{6}-13.50 \times 10^{6} / \mathrm{ml}[16]$ and $9.9 \times 10^{6}-$ $18.7 \times 10^{6} / \mathrm{ml}$ [17] reported for WAD sheep and goats respectively. White blood cell (Leukocyte) count is a test that measures the white blood cells (WBC) in the body. It plays an important role in fighting against diseases and protection from infections. WBC count was similar for goats in T2 $\left(15.50 \times 10^{6}\right)$ and T3 $(14.60 \times$ $\left.10^{6}\right)$ but differ from the values of T1 $\left(12.80 \times 10^{6}\right)$ which is the control and T4 $\left(7.25 \times 10^{6}\right)$. WBC values in this study can be comparable to the values $(6.80$ $20.1 \times 10^{6}$ ) reported by [14] for haematological and biochemical parameters of WAD goats. The animals suffer any disease condition throughout the study period which revealed that feeding the test diets did not affect their health negatively. Mean Corpuscular volume $(23.98 \mathrm{fl}-33.00 \mathrm{fl})$ was higher than $22.19 \mathrm{fl}$ $24.63 \mathrm{fl}$ reported by [18] for Haematological and serum biochemical indices of WAD goats with foreign body impaction and $21.83 \mathrm{fl}-22.18 \mathrm{fl}$ reported by [19] 
for Blood profiles of WAD bucks fed varying levels of Shea nut cake based rations in Nigeria but within the normal healthy range reported by [14] and [20] for WAD goats. Mean Corpuscular Haemoglobin and Mean Corpuscular Haemoglobin Concentration were not significantly different within dietary treatment. The animals did not suffer any disease condition throughout the study period which revealed that feeding the test diets did not affect their health negatively. $\mathrm{MCH}$ and $\mathrm{MCHC}$ further buttress the fact that the animals were not anaemic.

The biochemical indices presented in Table 4 did not show any significant variation $(\mathrm{P}>0.05)$ amongst treatment except for the transaminases (AST and ALT). Total protein reduced steadily from $\mathrm{T} 2(5.45 \mathrm{~g} / \mathrm{l})$ to $\mathrm{T} 4(4.73 \mathrm{~g} / \mathrm{l})$ and showed no significant difference. [21] found that serum protein is important in osmotic regulation, immunity and transport of several substances in body. The lower values for Total protein, Albumin and Globulin in this study which were similar to that of [22] indicated that there were no traces of anti-nutritional factors that could diminish nutrient permeability in the gut walls [22].

Cholesterol values were high compared to authors elsewhere [1] and [19], this indicates that the meat quality was not safe for consumers avoiding high cholesterol content. Since there was no variation in Urea treatments it showed utilization of Baobab seed meal as protein and energy sources did not cause any deleterious effect on the goats despite the high values $(24.80-35.65 \mathrm{mmol} / \mathrm{l})$ which were above the normal serum urea $(3.5-9.70 \mathrm{mmol} / \mathrm{l})$ reported for WAD goats by [14].

The creatinine content $(1.98 \mathrm{mg} / \mathrm{dl}-2.18 \mathrm{mg} / \mathrm{dl})$ in this study was higher than the values $(0.70-1.5 \mathrm{mg} / \mathrm{dl})$ reported by [23] and $0.9-1.8 \mathrm{mg} / \mathrm{dl}$ reported by [24] for normal values of creatinine for goats. However, the animals did not suffer any muscular wastage or kidney disease connected to high creatinine level in goats.

The concentrations of AST and ALT varied significantly, ranged from 14.75 $\mathrm{u} / \mathrm{l}-35.50 \mathrm{u} / \mathrm{l}$ and $14.85 \mathrm{u} / \mathrm{l}-51.47 \mathrm{u} / \mathrm{l}$ respectively. Serum transaminases (AST) concentration in the blood was reliable tests for liver damage; however, values obtained in this study did not indicate any malfunctioning of the liver of the experimental animals.

\section{Conclusion}

The inclusion of baobab seed meal up to $50 \%$ in the experimental diet did not have any negative effect on the performance of the goats and did not pose any health challenge to the animals during the study period. Baobab can serve as a feed resource in supplementing diets for grower WAD goats and can be utilized during the dry season when there is a shortage of feed due to its abundance and availability all year round.

\section{Conflicts of Interest}

The authors declare no conflicts of interest regarding the publication of this paper. 


\section{References}

[1] Ikyume, T.T., Eigege, N.N., Bashi, D.T., Oche, N.P., Abdulraheem, A.I., Ojabo, M. and Akalika, I.P. (2018) Growth Performance, Blood Profile and Economics of WAD Goats Fed Fermented Baobab (Adansonia digitata) Seed Meal. Animal Husbandry and Dairy Science, 2, 30-36.

[2] FAO (1988) Traditional Food Plants. Food and Agriculture Organisation (FAO/UN), Rome.

[3] Nkafamiya, I., Osemeahon, S., Dahiru, D. and Umaru, H. (2007) Studies on the Chemical Composition and Physiocochemical Properties of the Seeds of Baobab (Adansonia digitata). African Journal of Biotechnology, 6, 656-659.

[4] Gurbuz, Y. and Alarson, O.F. (2017) The Effects of Different Supplemented Pellets, Binders in Lambs Diet on Fattening Performance and Carcass. Journal of Animal Production, 58, 15-23.

[5] Longvah, T., Deosthale, Y.G. and Kumar, P.U. (2000) Nutritional and Short Term Toxicology Evaluation of Perilla Seed Oil. Food Chemistry, 70, 13-16.

https://doi.org/10.1016/S0308-8146(99)00263-0

[6] Ewuola, E.O., Jimoh, O.A., Atuma, O.V. and Soipe, O.D. (2012) Haematological and Serum Biochemical Response of Growing Rabbit Fed Graded Levels of Graded Levels of Moringa oleifera Leaf Meal. Proceedings, 10 th Annual World Rabbit Congress, Sharm El-Sheikh, 3-6 September 2012, 679-683.

[7] Balikei, E., Yildiz, A. and Gurdogan, F. (2007) Blood Metabolite Concentrations during Pregnancy and Post-Partum in Akkaraman Ewes. Small Ruminant Resource, 67, 247-251. https://doi.org/10.1016/j.smallrumres.2005.10.011

[8] T.A.C. (2009) Makurdi Weather Element Records. Nigerian Air Force Tactical Air Command. Makurdi Metrological Station, Makurdi.

[9] A.O.A.C. (1995) Official Method of Analysis. 16th Edition, Association of Analytical Chemists, Washington DC.

[10] Steel, R.G.B. and Torrie, S.A. (1990) Preambles and Procedures of Statistics. A Biological Approval. 2nd Edition, McGraw-Hill Book, New York.

[11] Minitab (2016) Statistical Software, Version 16. Minitab Incorporation, State College.

[12] Illori, H.B., Salami, S.A., Makoja, M.A. and Okunda, D.O. (2013) Acceptability and Nutrient Digestibility of WAD Goat Fed Different Dietary Inclusion of Baobab (Adansonia digitata). IOSR Journal of Agriculture and Veterinary Science, 6, 22-26. https://doi.org/10.9790/2380-0632226

[13] Ukanwoko, A.I. and Onuoha, C.A. (2011) Growth Performance and Characteristics of West African Dwarf (WAD) Goats Fed Oil Palm Leaf Meal-Cassava Peel Based Diets. Continental Journal of Animal and Veterinary Research, 3, 1-6.

[14] Daramola, J.O., Adeloye, A.A., Fatoba, T.A. and Soladoye, A.O. (2005) Haematological and Biochemical Parameters of West African Dwarf Goats. Livestock Resource for Rural Development, 17, 3-5.

[15] Blood, D.C., Studdert, V.P. and Gay, C.C. (2007) Sanders Comprehensive Veterinary Dictionary. 3rd Edition, Elsevier, Oxford.

[16] Tambuwal, F.M., Agale, B.M. and Babagana, A. (2002) A Haematology and Biochemical Values of Apparently Healthy Red Sokoto Goats. Proceedings of the 27 th Annual Conference of Nigerian Society for Animal Production (NSAP), Akure, 17-21 March 2002, 50-53.

[17] Taiwo, V.O. and Ogunsanmi, A.O. (2003) Haematology, Plasma, Whole Blood and 
Erythrocyte Biochemical Values of Clinically Healthy Captive-Reared Grey Duiker (Sylvicarpa grimmia), West African Dwarf Sheep and Goats in Ibadan, Nigeria. Israel Journal of Veterinary Medicine, 5, 43-47.

http://www.isrvma.org/article/5823htm

[18] Akinrinmade, J.F. and Akinrinde, A.S. (2012) Haematological and Serum Biochemical Indices of WAD Goats with Foreign Body Rumen Impaction. Nigerian Journal of Physiological Science, 27, 83-87.

[19] Ogunbosoye, D.O., Abayomi, A. and David, A.A. (2018) Blood Profiles of WAD Growing Bucks Fed Varying Levels of Shea Nut Cake Based Rations in Nigeria. Cogent Food and Agriculture, 4, Article ID: 1474620. https://doi.org/10.1080/23311932.2018.1474620

[20] Belewu, M.A. and Ojo-Alokomaro, K.O. (2007) Haematological Indices of West African Dwarf Goat Fed Leaf Meal Based Diets. Bulgaria Journal of Agricultural Science, 13, 601-606.

[21] Ikhimioya, I. and Imaseun, J.A. (2007) Blood Profile of West African Dwarf Goats Fed Panicum Maximum Supplemented with Afzeila africana and Newbouldia laevis. Pakistan Journal of Nutrition, 6, 79-84. https://doi.org/10.3923/pjn.2007.79.84

[22] Ogunleke, F.O., Ajayi Morakinyo, O.A. and Saka, A.A. (2014) Performance and Blood Profile of West African Dwarf Goat Fed Concentrate Supplement Containing Varying Levels of Corncobs. American Journal of Experimental Agriculture, 4, 1861-1868. https://doi.org/10.9734/AJEA/2014/11271

[23] Fraser, C.M. (1986) The Merck Vet Manual. 6th Edition, Merck and Co. Inc., Rahway.

[24] Kaneko, J.J. (1989) Clinical Biochemistry of Domestic Animals. 4th Edition, Academic Press, San Diego, 117-120. 